УДК 630

DOI: https://doi.org/10.54929/pmt-issue1-2021-12

\title{
FINANCIAL SUPPORT OF MODERN TECHNOLOGICAL TRANSFORMATIONS
}

\section{ФІНАНСОВЕ ЗАБЕЗПЕЧЕННЯ СУЧАСНИХ ТЕХНОЛОГІЧНИХ ПЕРЕТВОРЕНЬ}

\author{
Anastasiia Duka \\ Doctor of Economic Sciences, Professor, \\ Professor at the Department of Public Administration \\ and Organizations' Management \\ Chernihiv Polytechnic National University, Chernihiv \\ ORCID: 0000-0001-7682-4274
}

Дука А. П. доктор економічних наук, професор профессор кафедри публічного управління та менеджменту організацій, Національний університет «Чернігівська політехніка», Чернігів

The main directions of financial support of modern technological transformations on the basis of systematization of the basic sources of financing of researches and developments are investigated. It is substantiated that modern technological transformations require the accumulation of a significant amount of resources, and therefore all the main tools of fiscal regulation should be used. The main arguments for resuming the practice of preferential taxation are considered. The world experience of using fiscal instruments and significant directions of their distribution in the national economy are generalized. The importance of intensifying the state's participation in supporting and stimulating the innovative activity of economic entities as the main carriers of demand and high-tech products was emphasized. The list of contradictions in the application of fiscal instruments is outlined and the importance of their leveling for the further socio-economic development of the country is emphasized. It is determined that the financing of technological transformations is insufficient to ensure significant changes and restore the country's industrial potential. A number of ways to improve the financial support of technological changes are proposed. Key words: sources of financing, innovative development, technological shifts, financial support, financial resources, fiscal instruments.

Досліджено основні напрями фрінансового забезпечення сучасних технологічних перетворень на основі систематизації основних джерел фрінансування досліджень і розробок. Обгрунтовано, що сучасні технологічні перетворення потребують акумулювання значного обсягу ресурсів, а тому мають бути задіяні всі основні інструменти фріскального регулювання. Аргументовано, що лише у випадку систематичного спрямування необхідних фрінансових ресурсів у достатньому обсязі для створення високотехнологічних виробництв та промислового освоєння результатів досліджень і розробок, може бути досягнуто кумулятивного ефекту від науково-технічної та інноваційної діяльності. Це пов'язано з підвищенням складності науково-технічних розробок, вимогливості запитів споживачів і відповідно подорожчанням їх виконання. Розглянуто основні аргументи щодо поновлення практики пільгового оподаткування. Узагальнено світовий досвід використання фіскальних інструментів та визначні напрями їх поширення в національній економіці. Наголошено на важливості активізації участі держави у підтримці та стимулюванні інноваційної активності суб'єктів господарювання як основних носіїв попиту та високотехнологічну продукцію. Окреслено перелік суперечностей у застосуванні фіскальних інструментів та акцентовано на важливості їх нівелювання для подальшого соціально-економічного розвитку країни. Визначено, що стимулювання науково-технічної та інноваційної діяльності у частині виокремлення фіскальних інструментів $є$ досить різноманітною та диференційованою й дає підстави взяти до уваги позитивний досвід. Практика використання податкових стимулів та пільг змінюється та удосконалюється. Якщо спершу основними поширеними інструментами стимулювання активності у сфрері досліджень та розробок було зменшення бази оподаткування, то ускладнення самої інноваиійної діяльності, диверсифрікованість фрінансових джерел забезпечення, ускладнення інноваційних процесів спричинили зміни і самих інструментів фріскального стимулювання. Визначено, що фрінансування технологічних перетворень недостатнє для забезпечення суттєвих зрушень та відновлення промислового потенціалу країни. Запропоновано низку напрямів удосконалення фрінансового забезпечення технологічних зрушень. Ключові слова: джерела фрінансування, інноваційний розвиток, технологічні зрушення, фрінансове забезпечення, фрінансові ресурси, фріскальні інструменти. 
Исследованы основные направления финансового обеспечения современных технологических преобразований на основе систематизации основных источников финансирования исследований и разработок. Обосновано, что современные технологические преобразования требуют аккумулирования значительного объема ресурсов, а потому должны быть задействованы все основные инструменты фрискального регулирования. Аргументировано, что только в случае систематического направления необходимых фринансовых ресурсов в достаточном объеме для создания высокотехнологичных производств и промышленного освоения результатов исследований и разработок, может быть достигнуто кумулятивного эфффекта от научно-технической и инновационной деятельности. Это связано с повышением сложности научно-технических разработок, требовательности запросов потребителей и соответственно удорожанием их выполнения. Рассмотрены основные аргументы о возобновлении практики льготного налогообложения. Обобщен мировой опыт использования фискальных инструментов и выдающиеся направления их распространения в национальной экономике. Подчеркнута важность активизации участия государства в поддержке и стимулировании инновационной активности субъектов хозяйствования как основных носителей спроса и высокотехнологичную продукцию. Определены перечень противоречий в применении фискальных инструментов и акцентировано на важности их нивелирования для дальнейшего социально-экономического развития страны. Определено, что стимулирование научно-технической и инновационной деятельности в части выделения фрискальных инструментов является достаточно разнообразной и дифференцированной и дает основания принять во внимание положительный опыт. Практика использования налоговых стимулов и льгот меняется и совершенствуется. Если сначала основными распространенными инструментами стимулирования активности в сфере исследований и разработок было уменьшение базы налогообложения, то осложнения самой инновационной деятельности, диверсификация фринансовых источников обеспечения, осложнения инновационных процессов вызвали изменения и самих инструментов фискального стимулирования. Определено, что фринансирование технологических преобразований недостаточно для обеспечения существенных сдвигов и восстановления промышленного потенциала страны. Предложен ряд направлений совершенствования финансового обеспечения технологических сдвигов. Ключевые слова: источники фринансирования, инновационное развитие, технологические сдвиги, фринансовое обеспечение, финансовые ресурсы, фискальные инструменты.

Formulation of the problem. Timely and complete provision of technological changes with financial resources is especially important today. As the world experience and practice of realization of innovation priorities of Ukraine testify, insufficiency of volumes of financing and limitedness of the basic financial sources creates additional difficulties for effective formation of innovative model of development of national economy. The development of an innovative economy involves more complex scientific and technical developments, more demanding consumer demands and, accordingly, the more expensive their implementation. Only in the case of systematic allocation of the necessary financial resources in sufficient quantities to create high-tech industries and industrial development of research and development results, a cumulative effect of scientific, technical and innovative activities can be achieved. Thus, the importance of financial resources for the development of innovation processes is characterized by the complexity of their involvement and dependence on many factors that are difficult to predict.

Analysis of recent research and publications. Problems of financial support of the innovative model of development of the national economy are widely discussed in scientific circles in recent years. A number of works by well-known scientists, in particular, Yu. Bazhal, M. Krupka, V. Osetsky, L. Fedulova, Y.Shahid, W. K. Shuilin etc. are devoted to these areas of scientific research. In the field of works of these authors the scientific basis for development of information space for development of Ukraine is formed, the basic innovative priorities and directions of improvement of financial maintenance of increase of scientific and technical and innovative potentials are defined.

Formulation of the goals of the article (task statement). The purpose of the article is to study the financial support of technological transformations and determine the prospects for its improvement in the context of transformational change.

Presentation of the main research material. A significant breakthrough in technology and information encourages Ukraine to focus on new sources of competitive advantage and create them. The current stage of development is associated with a reasonable choice of the appropriate place among the components of dynamic comparative advantages of scientific and technological advances at all stages of the product life cycle, from the creation of a product or service to subsequent disposal. And this requires an increase in funding, expanding funding sources and access to them for all participants in the innovation process. In addition, as a result of the dependence established by N. Rescher, to double the number of inventions for a certain period of time, it is necessary to use 100 times more resources for the same period. Accordingly, to obtain three times more inventions, it is necessary to spend 1000 times more resources. The high level of research and development costs characterizes organizations operating in the innovation sphere of the economy.

In view of this, the competitiveness of the national economy increasingly depends not only 
on the specific producer, but also on the ability of the national environment and its participants to accompany and use new products. The demand for the integrity of such an environment, the qualifications and solvency of its participants is growing sharply. Innovative type of economic development is increasingly becoming the foundation that determines the economic power of the country and its prospects in the world market.

However, implementing a policy of regulating and stimulating innovative development, the state is forced to constantly solve the problem of balancing the distribution of public resources. The traditional dilemma of public choice in establishing the relationship between the production of consumer and industrial products is supplemented by another key element-science. And as the practice of recent years shows, the choice is mostly not in favor of science. By investing in stimulating consumer demand, society distracts them from investment and innovation. The decision to concentrate funds on the implementation of innovative projects, in turn, leads to a relative reduction in consumption and current production and investment. This is especially noticeable in conditions of stagnation in the economy. Meanwhile, according to M. TuganBaranovsky, in the long run it is technological changes that can form aggregate demand [1, pp.3-267].

Therefore, we should agree with the opinion, which does not lose its relevance, that at the expense of centralized financial resources it is advisable to finance vital innovative projects for the country. In this case, the non-refundable provision of budget funds in the form of subsidies should be considered as an exception to the rules, based on the basic principles of lending, in particular, urgency, return and payment. To increase the return on budget allocations to support innovation, it is recommended that the following principles be followed [2, p.396]:

The principle of rapid return, when funds are invested in existing innovative projects that are under implementation, or projects that require minor refinement. The return is not only the return of funds spent, but the return of invested resources with an increase in value added and profit or an effect that has no material embodiment and only indirectly affects the efficiency of the economy;

The principle of distribution with a time lag when it comes to investing in innovative projects, covering all areas of the economy. This principle is quite relevant when it comes to the lack of resources to fully support all innovative programs of national importance.

Mixed funding schemes may be used for some cross-sectoral, cross-sectoral and regional science and technology and innovation projects and programs. In this case, the financing of projects prepared by commercial structures should be carried out on a competitive basis, provided that at least $70 \%$ must be covered by the initiator's own funds, and $30 \%$ can be financed by annual expenditures from the state or local budget. Extrabudgetary funds may also be involved in financing such projects. As the practice of financing projects with the involvement of international financial institutions, in particular the EBRD, compliance with the ratio of $70: 30$ in the structure of project financing, provides additional guarantees for the lender to repay loans.

Many studies emphasize the need to stimulate lending operations of banking institutions aimed at bringing them closer to the real sector of the economy and based on increasing banks' interest in lending to innovation. Thus, it is appropriate to consider the resumption of the practice of preferential taxation depending on the operations with long-term loans, the intended use of which provides for the implementation of new construction, modernization, reconstruction and technical reequipment; reduction of the norms of obligatory reservation of funds on the correspondent accounts of the National Bank of Ukraine.

However, in order to obtain the relevant preferential terms, additional control methods must be applied, as in practice it is quite common for the subject of a contract under a modernization project obtained from abroad to be overpriced and not only morally but also physically obsolete.

Countries that successfully finance innovative change use a fairly large arsenal of tools to ensure the accumulation and placement of capital for the strategic interests of the country. Due to this, the world practice has accumulated various methods of encouraging long-term investment. These include easing the tax burden on institutions that make technological changes, providing them with benefits and setting quotas for organizations in the field of science and technology, which are distributed to ensure their interest-free repayment, widespread use of non-traditional investment methods.

Given the limited number of sources of funding (own funds, state budget and customer funds) and the unavailability of most of them for organizations of science and technology due to the probabilistic nature of the expected result and lack of satisfactory collateral for financial institutions, lack of adequate investment resources for projects technical reequipment and reconstruction of production facilities, special attention is paid to the search and use of new sources, forms and methods of financial support of scientific, technical and innovative activities. Thus, along with traditional banking technologies - loans, which are used to finance projects of enterprises, there are new ones - franchising, leasing, factoring, 
The main sources of financial support for technological changes and technological renewal of the economy

\begin{tabular}{|c|c|}
\hline Target budget sources & $\begin{array}{l}\text { Funds of special funds for financing } \\
\text { research and development }\end{array}$ \\
\hline $\begin{array}{l}\text { Financial resources of business } \\
\text { entities }\end{array}$ & Credit resources of banks \\
\hline Foreign income & $\begin{array}{l}\text { Funds of domestic and foreign } \\
\text { scientific, innovation and venture } \\
\text { funds }\end{array}$ \\
\hline Private equity (fundraising) & $\begin{array}{l}\text { Funds of scientific organizations (start- } \\
\text { ups, grants) }\end{array}$ \\
\hline
\end{tabular}

Fig. 1. Sources of financial support for technological changes and technological renewal of the economy

Source: systematized by the author

forfeiting, grant financing, startups.

Summarizing the well-known sources of financial security, it is worth emphasizing the ability of most of them to provide modern technological change, in particular, among such sources it is advisable to highlight Fig.1.

According to Kokurin D., a form of indirect financing of innovation activities that helps to reduce development costs. is a franchise [3, p.327]. Its use makes it possible to attract capital from many investors seeking to become entrepreneurs. This capital can far exceed the amount of capital that can be raised in the traditional way. The scheme of franchising is as follows: the franchisor transfers or sells a license - a franchise - for the right to sell products or do business in a certain area using a trademark and provided that the franchisee meets the requirements of quality and technology. As a rule, the franchise is provided by a leading company with a high image, which tries to combine its high technologies and know-how with the capital of the franchisee, thus ensuring the transfer of advanced technologies.

In general, franchising should be used for replication of science-intensive products, with the involvement of large capital. In addition to financial resources, intangible assets may be transferred to the innovator during franchising. Thus, the main advantage of franchising for financial support of knowledge-intensive products is the combination of the advantages of credit and leasing. The use of leasing can be regarded as an additional opportunity to solve the problem of mobilization of unused commodity resources and their involvement in economic turnover. Financing in this way is most often used in industries with a high degree of business risk, in new markets. It has significant advantages over other types, especially in the field of innovation, as it is a specific form of attracting productive capital, a way to capitalize investments. In addition, leasing is able to open access to the most advanced equipment and create conditions for resolving the contradiction between the need to use advanced technologies and its rapid obsolescence [4, pp.193-293].

Innovative economy is formed on the use of new technologies, ie covers all economic entities, and involves a new system of economic relations 
between them, formed in a common sequence for all countries, which in a simplified version has the form [5]: creation of new technologies $=>$ increase in entrepreneurial costs for continuous training and retraining of workers $=>$ decrease in production costs and prices for consumer goods and services $=>$ change in the structure of demand for goods and services $=>$ increase in household expenditures on education $=>$ increase the quality of the population $=>$ change in the structure of national wealth $=>$ formation of a new system of interests $=>$ revision of the criteria for economic growth.

Thus, the main elements of the national innovation system include: science (system of knowledge generation and dissemination); innovative production sector; education focused on the training of highly qualified specialists; innovation infrastructure; mechanisms to support innovation.

In addition to the use of non-traditional financing methods, it is also necessary to abandon the policy of reducing the degree of participation of the state and local authorities in the investment process. The practice of selecting projects for public funding based on the principle of their quick payback should be avoided. The non-refundable allocation of budget funds should be based on credit principles and focus on vital innovative projects that affect the development of the national economy [2, pp.393-398]. Therefore, the activity of using various sources of financial support for the innovation sphere is possible by supplementing the resources of business structures with appropriate funds at the state level.

However, it should be noted that in most developed countries a significant share of scientific and scientific-technical work is financed mainly by business entities, and the state uses diversified forms of their stimulation. The relatively insignificant (up to 10\%) level of expenditures on scientific and technical work by national customers is explained by low effective demand for scientific developments, and the objective limited budget resources do not allow to provide large-scale innovation processes in the economy and increase funding for research and development. sector, nor at the level of budget funding. Thus, in the modern realities of the national economy, the issue of improving the fiscal policy of the state, the selection of the most effective fiscal instruments to stimulate innovation in industrial activities is becoming increasingly important.

In the modern interpretation, the term «fiscal» is used as a state accumulation of values (money, jewelry and other tangible and intangible assets) to perform their functions. The variation of fiscal instruments is quite diversified and includes simultaneous application [6; 7]:

- public investment;

- public procurement and public procurement;
- direct state funding of social programs;

- state transfers;

- tax burden management, variation of direct and indirect taxes, establishment of tax benefits

Fiscal policy manipulates the budget, smoothing business cycles and ensuring the country's economic growth. Lower tax rates do not necessarily lead to a reduction in tax revenues, as general tax discipline increases. The American economist A. Laffer found that even when taxpayers withdraw more than $30-40 \%$ of their income, they begin to reduce savings and, consequently, investment in the national economy. Empirically, Laffer found that a reduction in corporate income tax rates by $1 \%$ leads to an increase in output by $2 \%$, and this pattern is in the range from 32 to $20 \%$. Further reduction of the income tax rate (as well as other taxes) is no longer as effective. The essence of the Laffer effect is that the reduction of tax rates causes only a short-term decline in government revenues and an increase in the budget deficit. In the long run, this measure provides an increase in savings, investment, production, employment and, consequently, total taxable income.

Among the main fiscal instruments through which the state influences the general course and nature of innovation processes, the most common are tax benefits. The active use of tax incentives for the development of science and innovation began during the period of active industrialization of the 1960s in leading countries during the implementation of the Keynesian model of economy and the development of a flexible system of tax regulation. Tax benefits have proved to be an effective tool for intensifying scientific, technical, innovative and industrial activities in the direction of reproducing the technological basis of economic transformations, increasing the competitiveness of the economy, attracting additional investment flows into research and development (Table 1).

Thus, the policy of stimulating scientific, technical and innovative activities in terms of the allocation of fiscal instruments is quite diverse and differentiated and gives grounds to take into account the positive experience in shaping the policy of innovative industrialization [5]. The policy of using tax incentives and benefits is changing and improving. If we take into account that initially the main common tools to stimulate activity in research and development were to reduce the tax base, the complexity of innovation, diversification of financial sources, complication of innovation processes caused changes in the fiscal stimulus itself. As an example, the exemption from income tax on the sale of securities or property reinvested in the production of profits in Canada. At the same time, the use of tools aimed at stimulating the activity of innovation and investment activities causes a lot of complaints 
World experience of use and variability of fiscal instruments

\begin{tabular}{|c|c|c|}
\hline Option to use tax benefits & $\begin{array}{l}\text { Advantages of } \\
\text { application }\end{array}$ & Country of distribution \\
\hline $\begin{array}{l}\text { Deduction of current costs for } \\
\text { research and development from } \\
\text { the tax base }\end{array}$ & $\begin{array}{l}\text { Expanding research and } \\
\text { development funding }\end{array}$ & $\begin{array}{l}\text { Australia, Denmark, } 125 \% \text { of the actual costs of } \\
\text { scientific and technical work, which exceeds } 20 \\
\text { thousand Australian dollars per year, are deducted } \\
\text { from the gross costs; Austria (105\%), Belgium, } \\
\text { Germany, Great Britain, Spain, Italy, Canada, the } \\
\text { Netherlands, Norway, Sweden, Switzerland, Japan } \\
(100 \%)\end{array}$ \\
\hline $\begin{array}{l}\text { Withdrawal from the object } \\
\text { of taxation of depreciation } \\
\text { calculated by the accelerated } \\
\text { method }\end{array}$ & $\begin{array}{c}\text { Increasing profits and } \\
\text { accelerating the renewal of } \\
\text { production, technological } \\
\text { and scientific equipment }\end{array}$ & $\begin{array}{c}\text { Australia, Belgium, USA, France - proportional } \\
\text { write-off within } 3 \text { years; Austria, Italy - accelerated } \\
\text { depreciation }\end{array}$ \\
\hline $\begin{array}{c}\text { Research tax credit and } \\
\text { withdrawal from the tax base } \\
\text { of interest payments on loans } \\
\text { obtained to upgrade the } \\
\text { production base and purchase } \\
\text { scientific and technical products } \\
\end{array}$ & $\begin{array}{l}\text { Releasing the amount of } \\
\text { accrued tax payment and } \\
\text { expanding funding for } \\
\text { research and development }\end{array}$ & $\begin{array}{l}\text { Canada, the Netherlands (growth in proportion } \\
\text { to the cost of R\&D); Japan, France (growth in } \\
\text { proportion to the rate determined at the legislative } \\
\text { level) USA - includes the cost of laboratory and } \\
\text { experimental work in triplicate compared to the cost } \\
\text { of industry for research and development }\end{array}$ \\
\hline $\begin{array}{l}\text { Reduction of tax rates for } \\
\text { innovative enterprises (tax } \\
\text { subsidies) }\end{array}$ & $\begin{array}{l}\text { Expanding research and } \\
\text { development funding }\end{array}$ & $\begin{array}{c}\text { Great Britain - income tax for venture firms } 10 \% \\
\text { less than the usual rate; Japan - the difference } \\
\text { is } 12 \% \text {; Germany - } 7.5 \% \text { discount; USA - rate } \\
\text { for legal form of venture capital 0\%; France - tax } \\
\text { rate of funds invested in a venture project - } 0 \% \text {; } \\
\text { Canada - exemption from taxation of profits from } \\
\text { the sale of securities or property of reinvested in } \\
\text { the production of profits; Portugal, Spain, Australia } \\
\text { - large subsidies for large firms, Ireland, Spain, the } \\
\text { Netherlands - small firms }\end{array}$ \\
\hline
\end{tabular}

Source: systematized by the author for [7, pp. 371-378]

about the loss of state budget revenues, which leads to a review from time to time the appropriateness of their use. For example, it is estimated that as a result of preferential taxation and tax credits, government losses from tax rebates on scientific and technical activities at purchasing power parity are estimated in 2005 at $\$ 5.1$ billion for the United States and \$ 2.3 billion for Canada, France -1.0 billion dollars, Japan - 3.3 million dollars. However, despite such assessments, the effectiveness of innovation in the global technological space for these countries creates much more benefits

To solve the pressing problems in the national economy to intensify innovation processes, taking into account world experience is useful in terms of borrowing elements of fiscal stimulus, which largely led to positive changes and improved market mechanisms for convergence of science and industry in the development of investment and innovation processes.

Given the limited effective demand from national industry for new technologies, the state could intensify innovation through the use of statutory incentives. However, in the practical plane of implementation of fiscal instruments in Ukraine there are serious problems associated with two groups of reasons:

1) conjunctural reasons that demonstrate the application of erroneous practices regarding the abolition of legally prescribed instruments, in particular, the benefits established by the law on the State Budget for the year. This situation makes it unprofitable to spend on innovative production renewal, ordering scientific and technical products, which is not compensated due to unpredictability at the level of existing incentives. A striking example of this process is the abolition since 2005, provided for in the Laws of Ukraine "On Innovation», "On the special regime of innovation of technology parks», incentives that have not been sufficiently restored to date;

2) the effectiveness of the use of certain instruments on a national scale is achieved by focusing on achieving specific goals. Failure to take this principle into account when establishing benefits can lead to a waste of resources. That is why, given the insufficiency and limited budget funding, fiscal instruments are more useful for enterprises that implement comprehensive organizational and technological measures aimed at increasing the production of high-tech products, import substitution, job creation. However, according to reality, most of the provided preferential tax regimes, tax base reductions and other tools are used in the national economy to support export-oriented raw materials enterprises of low-tech industries or to implement projects without clear criteria for identifying innovative spending. An example is the 
establishment of a preferential tax regime for the mining and metallurgical complex, the exemption from taxation of foreign investors, who in the vast majority have implemented projects in the national economy in traditional markets.

Given that in recent years the volume of sold innovative products is significantly reduced, direct government funding for research and development is reduced, as well as reduced costs of enterprises to order scientific and technical products, intensification and variability of fiscal instruments in close combination with other elements of economic, innovation and industrial policy. is especially important for further innovative development of the economy.

The position of the state as the main carrier of demand for high technology and a social institution that can influence the development of science and technology is important in solving the problems of the current stage of modernization through the integration of research and development into the socio-economic environment. However, the inertia dominating in the modern political space leads to the fact that innovation-oriented programs and projects remain unrealized. As a result, socio-economic programs aimed at modernization reproduce the logic of quantitative economic growth. From the above we can conclude that the main problems are related to the objective nature of the process of technologicalization at the level of civilization, as well as the specifics of its institutional support in each country.

In the national economy, with significant potential in a number of branches of basic science, conditions for its practical use and expanded reproduction have not yet been created, which threatens further degradation of the field of research and development. The main problems that can be overcome by formulating a policy of innovation and industrial development include:

- insufficient ability to perceive technological innovations;

- inconsistency of research and development results with the real needs of the operation of industrial facilities;

- undeveloped system of intellectual property protection;

- inefficient functioning of technological transfer.

At the same time, the need for innovation is not met by effective demand due to the high risks ofinnovation itself, problems of access to long-term financial resources, technological backwardness of most enterprises. Demand for innovation is mainly formed in large companies, which mainly focus on low- and medium-tech industries.

Conclusions. Studies show that the modernization of the Ukrainian economy on the basis of innovative development should be ensured by the integrated use of all available sources of funding and the prevention of conflict between the solution of strategic and current challenges of economic development. The problem of stimulating innovation activity should be logically integrated into the fiscal policy of the state and based on the creation of such a system of fiscal instruments that would provide favorable conditions for innovation, creation of innovative products, attraction and differentiation of different sources of investment financing.

\section{REFERENCES:}

1. Tuhan-Baranovskyi, M. (1894). Promyslovi kryzy v suchasnii Anhlii, yikh prychyny i vplyv na narodne zhyttia [Industrial crises in modern England, their causes and impact on people's lives]. Kyiv. [in Ukrainian].

2. Krupka M. I. (2001). Finansovo-kredytnyi mekhanizm innovatsiinoho rozvytku ekonomiky Ukrainy [Financial and credit mechanism of innovative development of Ukraine's economy]. Lviv. : Vyd. tsentr Lviv. Nats. un-tu im. Ivana Franka. [in Ukrainian].

3. Kokuryn, D.Y. (2001). Innovatsionnaya deyatelnost' [Innovative activity]. Moskow, Ekzamen. [in Russian].

4. Chervanov, D.M. \& Neikova, L.I. (1999). Menedzhment innovatsiino-investytsiinoho rozvytku pidpryiemstv Ukrainy [Management of innovation and investment development of Ukrainian enterprises]. Kyiv, Znannia. [in Ukrainian].

5. Duka, A. P. (2014). Innovatsiina industrializatsiia natsionalnoi ekonomiky: Monohrafiia [Innovative industrialization of the national economy: Monograph]. Kyiv, VADEKS. [in Ukrainian].

6. Fiscal measures to promote R\&D and innovation. (1996). Paris. Organisation for Economic Co-operation and Development. OCDE/GD(96)165. Retrieved from http://www.oecd.org/ science /inno/2101604.pdf

7. Shahid, Y., Shuilin, W. K. (2005). NabeshimaFiscal policies for innovation. World Bank DECRG. Retrieved from http://siteresources.worldbank.org/ DEC/Resources/FiscalPolicies_forInnovation.pdf (December 6).

8. Fedulova, L. I., Bazhal, Yu. M., Osetskyi, V. L. ta in (2011). Tekhnolohichnyi imperatyv stratehii sotsialnoekonomichnoho rozvytku Ukrainy: monohrafiia [Technological imperative of strategy of social and economic development of Ukraine: monograph]. Kyiv, NAN Ukrainy; In-t ekon. ta prohnozuv. [in Ukrainian]. 